165

Received: July 25, 2012

Accepted: December 17, 2012
Macedonian Journal of Animal Science, Vol. 3, No. 2, pp. 161-168 (2013)

In print ISSN $1857-6907$

On line ISSN $1857-7709$

UDC: 636.39 .083

Original scientific paper

\title{
GOAT WELFARE DURING TRANSPORT
}

\author{
Şeniz Öziş Altınçekiç, Mehmet Koyuncu \\ Uludag University Faculty of Agriculture, Department of Animal Science, \\ 16059, Görükle, Bursa, Türkiye \\ senizozis@gmail.com
}

\begin{abstract}
Animal welfare is the combination of subjective and objective criteria of the life conditions of animals, including health and disease, behavior, husbandry and management. Transportation is an important activity of the farming industry and it is a topical controversial area of animal welfare. A high proportion of goats are transported at some stage in their lives, sometimes to places where food is more readily available, sometimes to a different owner or a different place of keeping and sometimes to slaughter. Transport can potential be stressfull for goats, as they are subjected to unfamiliar sights, sounds, smells, movements and processes of loading and unloading from the vehicle. Owners should therefore plan the process carefully to ensure that any risks to goat welfare are avoided. The frequency and duration of journeys should be minimised, whilst the conditions during transport should be optimised. The handling, loading, transporting and unloading of animals can have very substantial effects on their welfare. Distress during handling and transport of goats should be minimized. Goats should have an access to fresh water and feed during the rest periods on a long haul. Restraining and handling facilities should be free of sharp edges and objects. Goats in lactation require special care to assure comfort, and avoid udder injury and mastitis subsequent to transport. However, to maintain high standards of goat welfare, it is important to train employees in the farm.
\end{abstract}

Key words: goat; transportation; welfare

\section{БЛАГОСОСТОЈБА НА КОЗИТЕ ЗА ВРЕМЕ НА ТРАНСПОРТ}

Благосостојбата на животните претставува комбинација на субјективни и објективни критериуми на условите за живот, вклучувајќи здравје и болести, однесување, одгледување и менаџмент. Транспортот е важна активност на фармерството и тоа е тематски контроверзна област во рамките на благосостојбата на животните. Голем дел од козите се транспортираат во некоја фаза од нивниот живот, некогаш на места каде што храната е полесно достапна, некогаш кај друг сопственик или на некое друго место на чување, а понекогаш и за колење. Транспортот потенцијално може да биде стресен за козите бидејќи тие се подложени на непознати места, звуци, мириси, движења и процеси на утовар и растовар од возилото. Затоа сопствениците треба внимателно да го планираат процесот, за да се осигура дека се избегнати било какви ризици за благосостојба на козите. Фреквенцијата и времетраењето на патувањата треба да се минимизира, додека условите за време на транспортот треба да бидат оптимизирани. Држењето, товарењето, транспортот и истоварувањето на животните може да има значителен ефект врз нивната благосостојба. Болката за време на водењето и транспортот на козите треба да се минимизира. При долги дестинации козите треба да имаат пристап до вода за пиење и храна за време на одморот. Ограничувачките и помошните уреди не треба да имаат остри рабови. Козите во лактација бараат посебна грижа за да се обезбеди удобност и да се избегне повреда на вимето и појава на маститис после транспортот. Сепак за одржување на високи стандарди за благосостојба на козите, важна е и обуката на вработените во фармата.

Клучни зборови: коза; транспортирање; благосостојба

\section{INTRODUCTION}

Being one of the important activities in stockbreeding business, transportation is among the factors that create stress on animals and affect livestock welfare (Giovagnoli et al., 2002). Transpor- tation covers catching the animals, loading them onto the vehicle, transport and unloading for the purpose of transporting, and all these factors create stress on the animals. Also factors such as the animals' freedom of movement during the transport, the vibration and shocks on the vehicle, ambient 
temperature and level of moisture, inadequate ventilation and exhaust gases, water and feed restrictions, transport duration and the number of animals on the vehicle affect welfare negatively by creating intense stress on the animals (Van de Water et al., 2003; Fazio et al., 2005).

Livestock transportation is very important in terms of animal welfare, animal-human health and stockbreeding economy. Some of the conditions occurring either during, before or after the transport affect animal welfare and meat quality. Transports made with improper conditions cause economic losses via cases of animal mortality, injury and decreasing meat quality. For the sake of animal and public health, livestock transportation needs to be scrutinized. Uncontrolled movement of animals and livestock markets have major contribution to the spread of FMD (foot and mouth disease), brucella, tuberculosis and other contagious diseases. Welfare conditions have to be ensured during transport of animals with breeding and slaughter purposes (Anonymous, 2002; Yildiz and Hayirli, 2005).

Animal welfare may be affected by one or the composition of more than one application during transport. Due to this reason arrangements intended to increase livestock welfare were brought. As a matter of fact, with the intention to increase the protection of animals during transport, establishment of breeding systems taking animal welfare as a basis is requested and minimum standards were set (Anonymous, 2005b)

In this present review the factors affecting animal welfare before and during transport, the measures that need to be taken in order to minimize the negative effects of these factors on the animals and products, and the rules to be complied with within the frame of the related established standards were examined.

\section{THE RELATION BETWEEN TRANSPORT AND WELFARE}

In many studies concerning transport, it is stated that the loading and unloading of animals to and from the vehicle are the most stressful phases of transport (Hall and Bradshaw, 1998). The method used during handling, loading and unloading of animals affects animal welfare on a large scale. Goats are highly susceptible to the stress during transportation. If the breeders do not maintain animals properly and those who are responsible of transport preparation do not plan the trans- port properly, this susceptibility can result in animal pneumonia, dehydration, starvation, miscarriage or death. Due to this reason, the methods to be used during loading, transport and unloading have to be carefully planned in order to prevent any deterioration of animal welfare. Ensuring the health of the animals or selecting the animals fit for transport fall to the responsibility of the herd owner or breeder. The personnel taking care of the loading, transport and unloading of the animals have to be trained on the techniques necessary in order to conduct these tasks in a way that will not cause any trauma and that will minimize stress on the animals. Being knowledgeable on animal behaviors and having the facilities suitable for transport constitute great importance in terms of animal welfare during their handling and loading (Broom, 2005).

\section{FACTORS AFFECTING PRE-TRANSPORT WELFARE}

Some of the herd management methods applied in businesses can cause important problems on the animals. Due to this reason it is of great importance that the breeders are trained on the fact that animals are sensitive and vulnerable. At this point, the treatments of animals and their effects on animal welfare should not be ignored. The stress animals suffer during their gathering and loading to the vehicle is formed completely on the basis of the breeders' attitude during these operations. Beating of the animals by the breeders can cause pain and injuries to the animals. Breeders' disregard on the fact that such treatments can cause stress on the animals is due to the breeders' lack of knowledge on animal welfare. Proper planning of the transport is the most important factor affecting animal welfare (Broom, 2005).

\section{Planning the journey}

Adequate planning is a key factor affecting the welfare of animals during a journey. Before the journey starts, plans should be made in relation to:

- preparation of animals for the journey

- choice of road or rail

- the nature and duration of the journey

- vehicle/container design and maintenance, including roll-on/roll-off vessels

- required documentation

- space allowance

- rest, water and feed, and observation of animals en route 
- control of disease

- emergency response procedures.

Cases of goat injuries and diseases can be minimized when the course that will cause the least stress within the legal boundaries is selected and transport in the quickest way is achieved. In this context, it is of great importance that the breeders are well trained, knowledgeable on the basic animal behavior covering their seeing, hearing and smelling senses and capable of correctly interpreting these (Anonymous, 2009).

The person in charge of the transport of goats is also responsible for gathering them on the courtyard and for maintaining their welfare until placement in the final destination. When preparing the transport plan, these persons have to ensure the safe and suitable conditions for goats during loading, transport and unloading (Anonymous, 2005). During the preparations for the transport it is essential to keep in mind that goats are gregarious, social, inquisitive and nimble animals, have longterm memories where both positive and negative experiences are recorded, that they need to be approached not from behind but from somewhere they can see the person approaching, that they need to be gradually accustomed to the new applications and that they can cause injuries to themselves and to the personnel when held in a way that would excite or provoke them (Anonymous, 2002). It is essential to provide adequate feed and water if the animals will be waiting for a period longer than 24 hours in the area they are gathered before transportation, will be kept without water for longer than 24 hours during the transport, or are weak, pregnant or have given birth recently (Anonymous, 2009).

Goats that must be handled and transported separately from other species. The following separations must also be applied (Anonymous, 2007) :

- Goats of significantly different sizes or ages.

- Sexually mature males from females.

- Animals with horns from animals without horns.

- Animals hostile to each other.

- Tied animals from untied animals.

\section{Loading and unloading ramps}

In livestock transportation, loading of the animals onto the vehicle is the phase causing the greatest stress. Animals are forced to leave the environment, and sometimes their social groups, they are accustomed to, to enter into an unfamiliar group of animals or into the vehicle, and to get over all these (Van de Water et al., 2003). Loading conditions (use of sticks or shock devices during loading) and particularly loading elements (loading ramp and dock) are factors that require physical effort from animals and affect their psychological stress levels at a large scale. Slippery surfaces, sharp edges or metal structures can injure animals and cause psychological and physical stress (Mounier et al., 2006). The direction of the slope of the ramp to be used is another factor causing stress. As a matter of fact, animals prefer moving upslope rather than downslope. In case that a slope surface will be used, it is necessary to ensure that the surface is sufficiently wide, not slippery and free of any projection on the sides in order to prevent injuries (Anonymous, 2005). The ramp and the passageway through which the animals will move have to be robust, and the gate leading to the passageway and the passageway have to be adequately wide in order to enable animals to pass without hurting and injuring each other. Feet of the animals must not sink into the floor and the structure itself has to prevent animals from jumping or falling. Ideally, the slope of the ramp to be used for loading goats onto the vehicle should be 20 degrees. Furthermore, there should be no gap between the ramp and the vehicle in order to prevent any animal from getting stuck in between and injured. Disorder during loading causes fluctuation in the animals' hormone and blood component levels and can cause heart rates two times faster (Anonymous, 2005a).

\section{Specifications of the transport vehicle}

In order to minimize the effects of the stress factors the animals are subjected to during the transportation from loading to unloading the use of a suitable vehicle for the transportation is essential. Vehicles used in animal transportation can vary from country to country and within the same country from region to region. However, no matter of the type of the vehicle used, all vehicles to be used in animal transportation must have the basic standards complying with the European Union Regulations on animal welfare during transportation (Kettlwell et al., 2001). According to the related EU Regulations, all animal transport vehicles, containers and their equipments have to be designed in a way that will prevent injuries and pain to the animals, and will ensure safety, thermal comfort and adequate levels of movement within the vehicle or container. The vehicle gate and corridors have to be designed with sufficient width in order 
to have easy and safe passage for the animals. Furthermore, transport vehicles have to prevent escape or fall of animals, keep animals under control and bear their weight. The floor of the vehicle has to be clean and dry and has to be coated with an anti-slip material in order to prevent slipping, falling and any injury of animals' feet and legs. It is required that the vehicles provide easy access to the animals in order to check and take care of them during the transport and enable cleaning and disinfection in order to minimize urine and feces contamination. Also, the partitions within the vehicle have to feature an easily and quickly installable mechanism, and have to be adjustable in order to care for the special needs of the animals during the transport (Anonymous, 2007). During transportation the animals should be able to stand upright in their normal position. If the height of stall starts right above the goat's head, this is an undesired situation. If the roof of the vehicle is also at the same height with the goat, high humidity and temperature due to bad air ventilation shall also trigger a good number of problems. On that account stall height should be, if inner-car ventilation operates well, $15 \mathrm{cms}$; if ventilation is poor it should be minimum $30 \mathrm{cms}$, deck height should also be adjusted in line with these measures. As regards goats, providing good air ventilation from the moment they are loaded on transportation vehicle bears critical importance for the health and welfare of goats. While being transported animals generally tolerate cold weather conditions but high temperature creates an adverse effect and fuels mortality rates (Gregory, 1998). For goats maximum heat tolerance level is $35-40^{\circ} \mathrm{C}$. In higher temperatures goats start to breathe faster. In order to protect animals from heat stress, transportation should be planned in the early morning or the late night when temperature is lower, busy highways and hours should be avoided, to avoid fast increase of innercar temperature, break lengths and intervals should be kept minimum and in hot weathers animals should be watered more frequently (Anonymous, 2005a).

\section{Factors Affecting Welfare During the Transport}

$90 \%$ of the livestock transports in EU member countries are made by road land transportation. During road transportation animals can be exposed to various internal and external stress factors. The conditions established during transportation are of great importance in terms of welfare. As the welfare level during transport decreases, product quality also decreases in line with the increasing stress on animals. This may even result in cases of mortality according to the duration and intensity of the stress. Factors such as loading of the animals to the vehicle, specifications of the loading and unloading ramp, area provided within the vehicle per animal, specifications of the transport vehicle (suspension system, height, ventilation in confinedspace vehicles, etc.), road and climate conditions have direct effects on welfare (Anonymous, 2002; Zanardi et al., 2007). Also the attitude of the operator driving the vehicle affects the welfare and protection of the animals. When the transport vehicle is driven carefully, the risk of fall within the vehicle decreases. While $75 \%$ of falls is caused by sudden brake and cornering, $25 \%$ is caused by bumps and acceleration. In order to prevent these it is necessary to accelerate slowly and without causing shake on the vehicle, be on alert as braking might be necessary at all times and slow down gradually by gently applying the brakes (Anonymous, 2005a).

\section{Space allowances}

Before a journey starts, there must be decisions about the space allowance for the animals on the vehicle and the grouping and distribution of animals. The space allocated per animal in the vehicles is among the important factors affecting welfare. While the space allocated per animal is expressed as $\left(\mathrm{m}^{2} /\right.$ animal $)$, the space allocated to a certain live weight is expressed as $\left(\mathrm{m}^{2} / 100 \mathrm{~kg}\right)$ and the live weight per unit space is expressed with $\left(\mathrm{kg} / \mathrm{m}^{2}\right)$. Loading density can be measured in several ways. Factors such as species, age, live weight, gender, pregnancy, transport duration, ambient temperature, and whether or not the animals are horned affect loading density (Knowles, 1998; Knowles et al., 1998). The farm Animal Welfare Council (FAWC) for the minimum acceptable area for all types of animals requires $A=0.021 \cdot W^{0.67}$ where $\mathrm{A}$ is the minimum floor area required by the animal in $\mathrm{m}^{2}$ and $W$ is the weight of the animal in $\mathrm{kg}$. The constant in the equation (0.021) depends on the shape of the animal, in particular the ratio of its body length to its body width. The allowed space for each animal during transport in EU standards is given in Table 1 (Anonymous, 2002).

Due to the fact that any loss of balance and falls within the vehicle cause unexpected injuries and crushes of the animals, appropriate animal density within the vehicle is highly important. In studies conducted on animal density in transport vehicles, it is reported that majority of mortalities during transport are caused due to the excessive 
number of animals situated on an unit area (Guardia et al., 1996; Riches et al., 1996).

Table 1

\section{Allowed space for each animal during transport in EU standards}

\begin{tabular}{lcc}
\hline $\begin{array}{l}\text { Average body weight } \\
(\mathrm{kg})\end{array}$ & $\begin{array}{c}\text { Approximate weight } \\
(\mathrm{kg})\end{array}$ & $\begin{array}{c}\text { Area } \\
\left(\mathrm{m}^{2} / \text { animal }\right)\end{array}$ \\
\hline Goats & $<35$ & $0.20-0.30$ \\
& $35-55$ & $0.30-0.40$ \\
& $>55$ & $0.40-0.75$ \\
$\begin{array}{l}\text { Heavily pregnant } \\
\text { goats }\end{array}$ & $<55$ & $0.40-0.50$ \\
\hline \hline
\end{tabular}

High density of animals within the vehicle makes it difficult for the animals to position themselves according to the driving directions. On the other hand, when the density of the animals loaded onto the vehicle is too low, animals may lose their balance because there are no other animals to lean on (Tarrant, 1990; Knowles, 1999). The stance of the animals largely depends on the area allocated per animal and transport conditions (Jarvis et al., 1996). Threatening and fighting behaviors between the animals and resulting injuries are observed due to the limited space per animal caused by excessive density within the vehicle. Resulting in high stress and low welfare levels, such conditions increase animals' susceptibility to diseases (Anonymous, 2002). In order to prevent injuries and bruising smaller goats should be separated from the larger ones. Otherwise, dominant goats may exhibit aggressive behaviors and injure smaller animals. Butting and goring are the most commonly observed behaviors in fights. An anti-slip space sufficient for the goat to be on its normal posture has to be allocated per animal and adequate level of underlay material has to be laid on this space. Before laying the material on the floor, adequate amount of sand has to be spread. Inadequate underlay material increases animal injuries (Anonymous, 2005a).

\section{Journey times}

Journey times and minimum resting periods are probably the most important areas of animal transport because of the possible economic impact of regulatory measures and the difficulty in obtaining information on existing practices (Andrea et al., 2008).
- Journey time is from the first animal loaded to the last animal unloaded.

- Time spent on Roll-on/Roll-off (RO-RO) vessels counts towards the journey time.

- Time spent by animals in pens on specialist livestock vessels does not count towards the total journey time, provided certain conditions are met.

- Time whilst on the aircraft during air transport does not count towards the total journey time.

Being not accustomed to being loaded and transported, animals undergo high levels of stress during the few hours following the loading. Although a certain level of adaptation to the new environment can be achieved later, with the increasing duration of transport stress level increases and negatively affects welfare. Therefore it is important to keep the transport duration as short as possible. The prolonging durations of transport will cause deteriorations in animal welfare, susceptibility to fatigue, lack of energy and diseases increases. European Union regulations stipulate that road transportation should not exceed 8 hours, and in case that it does extra measures such as artificial ventilation, provision of feed and water, etc have to be taken. In addition to these, at least two persons in charge of the transportation have to be present in the vehicle, drivers and other personnel have to have certificates of competence for the transport, sufficient number of personnel and necessary equipments have to be present, and it has to be documented that no major violation of the animal welfare regulation was made within the last three years. Standard and maximum transporting and resting periods (hour) for goats are given in Table 2 (Anonymous, 2007).

Table 2

Standard and maximum transporting and resting periods (hour) for goats

\begin{tabular}{lcccc}
\hline \hline & \multirow{2}{*}{$\begin{array}{c}\text { Basic Standard } \\
\text { vehicle }\end{array}$} & \multicolumn{3}{c}{ Higher standard vehicle } \\
\cline { 3 - 5 } & 8 & Travel & Rest & Travel \\
\hline Goats & 8 & 14 & 1 & 14 \\
Unweaned kids & & 9 & 1 & 9 \\
\hline \hline
\end{tabular}

\section{Unloading}

As the animals get accustomed to the vehicle during the transportation, they tend to be averse to move out of the vehicle. After the door of the vehicle is opened, a certain waiting period before the unloading starts should be allowed. In this way the 
animals will be prevented to move in a stunned condition and injure themselves by hitting around. Most farm animals prefer to walk on slightly upward slopes and from dark areas to lighted areas. Accordingly, use of lighting and such a sloped floor during unloading will ease the process. Loading feed and water has to be provided to goats in the shortest while possible. Goats in the 3rd phase of pregnancy, in the lactation period and younger than 7 days of age must not be left without water for a period longer than 12 hours. It has to be ensured that they consume water immediately at the arrival location (Anonymous, 2005a).

\section{Established Rules in Turkey Concerning Animal Transportation}

Within the scope of the EU harmonization studies in Turkey concerning animal welfare during livestock transportation, the 1/2005/EC numbered Council Directive regulating animal welfare during transportation and requiring certain arrangements to be made in terms of both regulations and practice was examined, and the 28145 numbered Regulation on Domestic Livestock and Animal Product Transportation of 17 December 2011 (Anonymous, 2011) and the 28152 numbered Regulation of Protection of Animals and Animal Welfare During Livestock Transportation of 24 December 2011 (Anonymous, 2011a) were announced on the basis of the 5996 numbered Veterinary Services, Plant Health, Food and Feed Law dated June $11^{\text {th }} 2010$. With the regulations the rules and procedures concerning the necessary conditions to have the animals conveyed to the intended domestic destinations in a safe and healthy way without maltreating them were set. Also the specifications of the transport vehicles as stipulated in the Notice of Fighting Animal Diseases and Control Movements of Animals set forth the conditions to be met for loading, transporting and unloading animals (Anonymous, 2012).

The regulations in Turkey concerning animal transport vehicles, loading, transportation and unloading of animals are as follows (Anonymous, 2012):

\section{ANIMAL TRANSPORT VEHICLES}

- Transport vehicles have to be designed in a way that will ensure safe transportation of animals.

- Animal transporting vehicles and containers have to be marked in a visible way from the out- side, with the indications that animals are being transported.

- Vehicle tops have to be covered in a way suitable to the weather conditions and ensuring adequate ventilation; the covers have to be strong and prevent animals to jump or escape.

- Adequate ventilation areas without restricting animals' movement and lighting sufficient for controlling and taking care of the animals have to be provided.

- At least $2 \mathrm{~cm}$ of a material that does not harm animal health or welfare such as litter, straw, hay, sawdust, etc. has to be spread on the floor of the transport vehicle and the covering of the floor has to minimize leaks of urine and feces. disinfected.

- Vehicles shall be easily cleanable and

\section{Loading and Unloading Animals}

- In cases where loading and unloading operations last for more than four hours, facilities enabling feeding and provision of water and providing a space for keeping the animals without tethering them have to be present next to the vehicle.

- Animals have to be loaded and unloaded with suitable ramps and in a way preventing any injuries and pain.

- Breeders in charge of the transport have to be adequately trained and carry out their duties without the use of any act of violence.

- During transport hitting or kicking animals, applying pressure to any sensible parts of their bodies in a way that causes unnecessary pain, suspending animals on mechanical equipments, lifting or dragging animals by holding from the head, eyes, ears, horns, tails, fur/skin, causing unnecessary pain, use of pointed tools are to be refrained from.

\section{Transport of Animals}

- Unregistered farm animals shall not be transported, physical and health conditions of the animals have to be fit for transport.

- In case of long transport durations (exceeding 8 hours), feed and water shall be provided at proper intervals.

- At the end of the transport animals shall be unloaded from the vehicle, provided with water and feed and left for rest for at least 24 hours. 
- Transport vehicles shall be fitted with a light colored roof and properly isolated.

- Sufficient amounts of feedstuff have to be present in the transport vehicle and feedstuff has to be preserved from dust, fuel, exhaust gas, urine, feces and weather conditions.

- In order to prevent collapse of feedboxes, feedboxes have to be fastened onto the vehicle. In cases where feedboxes will not be used, feedboxes have to be kept in a separate place.

- Provided that all within the vehicle animals will have free access to water, the vehicle shall be equipped with partition walls. Partition walls have to be designed in a way that will enable adjustment according to partition space, special needs and species, sizes and number of animals.

- The water system in the transport vehicle shall be in working condition and designed and positioned according to the species of the animals in the vehicle.

- Water tanks in the transport vehicle shall be emptied and cleaned after each trip and the water level shall be checked.

- Ventilation systems in the transport vehicle have to be designed in a way that enables maintaining inner temperature within the limits of 5 $30 \mathrm{C}^{\mathrm{o}}$, regardless of whether the vehicle is being driven or not.

- Nominal capacities of the ventilation systems in land transportation vehicles shall provide air distribution equal to $60 \mathrm{~m}^{3} / \mathrm{h} / \mathrm{KN}$ of the carrying capacity and the systems shall be capable of running minimum 4 hours independently from the engine of the vehicle.

-Transport vehicles shall be equipped with a system that will record temperature values and sound alarm when the temperature reaches the defined minimum or maximum values.

- Transport vehicles to be used for the first time and the currently used vehicles shall be equipped with a GPS system that will be capable of providing information on the opening of the loading door. The vehicles have to be equipped with such a GPS system latest by the date of DEcember $31^{\text {th }} 2015$.

\section{CONCLUSION}

The fact that the concept of animal welfare gains increasing importance in breeding systems recently in European Union countries and other developed countries caused the establishment of various standards that do not only focus on protecting animal health in animal production, import and export but also preservation of the animal welfare. In line with the developments in the world, animal welfare related approaches were recently brought into the agenda also in Turkey, and the legal regulations made were primarily focusing on the determination of welfare and transport conditions of farm animals.

Ensuring standardization according to species before transport and slaughter carries great importance in terms of both the quality of meat and meat products and monitoring animal behaviors and controlling diseases. As a matter of fact, problems occurring from ignoring animal welfare standards such as increase of animal mortality rates during transport, deformations in animal skeletons, loss of weight, decrease in meat quality set forth the importance of animal welfare rules. Transport of animals from business to business or from business to the slaughterhouse is a routinely conducted operation and several conditions occurring before, during and after transportation such as loading density, transport duration, loading and unloading ramps and the vehicle itself affect animal welfare. Knowing animals' needs and the stress factors affecting animals during transport and the effects of such factors according to the species, genders, ages, purpose of use as for slaughter or for breeding, and the basic measures to be taken within the scope of the related laws and regulations in order to minimize such effects carry a high level of importance.

\section{REFERENCES}

[1] Andrea, G., Ferrara, M., Simonin, D. (2008): Formulating Policies for The Welfare of Animals during Long Distance Transportation. Vet. Ital., 44 (1), 71-76.

[2] Anonymous (2000): Animal Care Series: Care Practices Goat. University of California Cooperative Extension. Published by the University of California, Davis; First Edition, May 2000. http://www.vetmed.ucdavis.edu/ vetext/inf-go_careprax2000.pdf / Accessed on 27 October 2008.

[3] Anonymous. (2002): The Welfare of Animals during Transport (Details for Horses, Pigs, Sheep and Cattle). Report of the Scientific Committee on Animal Health and Animal Welfare http://ec.europa.eu / Accessed on 27 October 2008.

[4] Anonymous (2005): Livestock Transport Vehicles. A Guide to Best Practice for Vehicle Ventilation. Published by the Department for Environment, Food and Rural Affairs. PB11260. www.defra.gov.uk / Accessed on 27 October 2008 . 
[5] Anonymous (2005a): Lowering Stress in Transported Goats. C. Richardson - Animal Care Specialist /OMAFRA. May 2005. / Accessed on 27 October 2008.

[6] Anonymous (2005b): Council Regulation 1/2005/EC on the Protection of Animals During Transport and Related Ope-

rations.http://eurex.europa.eu/LexUriServ/site/en/oj/2005/ 1_003/1_00320050105en00010044.pdf/ Accessed on 27 October 2008.

[7] Anonymous (2007): Welfare of Animals during Transport. Advice for Transporters of Goats. http://www.defra.gov.uk/publications/files/pb12544btransport-goats-110315.pdf/ Accessed on 27 October 2008.

[8] Anonymous. (2009): Australian Standards and Guidelines for the Welfare of Animals - land transport of livestock. Specific requirements for the land transport of goats. http://www.animalwelfarestandards.net.au/files/2011/02/ Australian-Animal-Welfare-Standards-and-Guidelinesfor-the-Land-Transport-of-Livestock.pdf/ Accessed on 10 December 2009

[9] Anonymous. (2011): Yurt içinde canlı hayvan ve hayvansal ürünlerin nakilleri hakkında yönetmelik. 17/12/2011 tarih ve 28145 say1l Resmi Gazete. http://www.resmigazete. gov.tr / Accessed on 15 February 2012.

[10] Anonymous. (2011a): Hayvanların nakilleri sirasında refah1 ve korunmas1 yönetmeliği. 24/12/2011 tarih ve 28152 sayılı Resmi Gazete. http:// www.resmigazete. gov.tr / Accessed on 15 February 2012.

[11] Anonymous. (2012): Hayvan hastalıkları ile mücadele ve hayvan hareketleri kontrolü genelgesi. Gıda, Tarım ve Hayvancılık Bakanlığı, Gıda ve Kontrol Genel Müdürlüğü 02/01/2012 tarih ve 001 sayılı genelge. http://www. gkgm.gov.tr/mevzuat/genelge/genelge liste.html / Accessed on 15 February 2012

[12] Broom, D. M. (2005): The Effects of Land Transport on Animal Welfare. Rev. Sci. Tech. Off. Int. Epiz., 24 (2), 683-691.

[13] Hall, S. J. G., Bradshaw, R. H. (1998): Welfare Aspects of Transport by Road of Sheep and Pigs. J. Appl. Anim. Welfare Sci., 1, 235-254.

[14] Giovagnoli, G., Trabalza Marinucci, M., Bolla, A. (2002): Transport Stress in Horses: An Electromyographic Study on Balance Preservation. Livest. Prod. Sci., $73,247-254$

[15] Fazio, E., Medica, D., Cavaleri, A. S. (2005): Effect of Long Distance Road Transport on Thyroid and Adrenal
Function and Haematocrit Values in Limousin Cattle: Influence of Body Weight Decresase. Vet. Res. Comm., 29, 713-719.

[16] Gregory, N. G. (1998): Animal Welfare and Meat Science. CABI Publishing, New York. pp. 398.

[17] Guardia, M. D., Gispert, M., Diestre, A. (1996): Mortality Rates during Transport and Lairage in Pigs for Slaughter. Meat Focus Int., 10, 362-366.

[18] Jarvis, A. M., Cockram, M. S., Mcgilp, I. M. (1996): Bruising and Biochemical Measures of Stres Dehydration and Injury Determined at Slaughter in Sheep Transported from Farms or Markets. Br. Vet. J., 152, 719-722.

[19] Kettlewell, P. J., Hoxey, R. P., Hampson, C. J., Green, N. R., Veale, B. M., Mitchell, M. A. (2001): Design and Operation of A Prototype Mechanical Ventilation System for Livestock Transport Vehicles. J. Agr. Eng. Res., 79 (4): 429-439.

[20] Knowles, T. G. (1998): A Review of The Road Transport of Slaughter Sheep. Vet. Rec., 143, 212-219.

[21] Knowles, T. G., Warris, P. D., Brown, S. N., Edwards, J. E. (1998): Effects of Stocking Density on Lambs Being Transported by Road. Vet. Rec., 142, 503-509.

[22] Knowles, T. G. (1999): A Review of The Road Transport of Cattle. Vet. Rec., 144, 197-201.

[23] Riches, H. L., Guise, H. J., Penny, R. H. C., Jones, T. A., Cuthbertson, A. (1996): A National Survey of Transport Conditions for Pigs. Pig J., 38, 8-18.

[24] Mounier, L., Dubroeucq, H., Andanson, S., Veissier, I. (2006): Variations in Meat $\mathrm{pH}$ of Beef Bulls in Relation to Conditions of Transfer to Slaughter and Previous History of the Animals. J. Anim. Sci., 84, 1567-1576.

[25] Tarrant, P. V. (1990): Transportation of Cattle by Road. Appl. Anim. Behav. Sci., 28, 153-170.

[26] Yildiz, A., Hayirli, A. (2005): Animal Transportation Made from The East of Turkey and Their Welfare. Proceeding of First Conference on Animal Welfare and Veterinary Education in Turkey. Ankara, Turkey, 140-144.

[27] Van De Water, G., Verjans, F., Geers, R. (2003): The Effect of Short Distance Transport Under Commercial Conditions on The Physiology of Slaughter Calves; $\mathrm{pH}$ and Colour Profiles of Veal. Livest. Prod. Sci., 82 (2), 171-179.

[28] Zanardi, E., Mussini, V., Ghidini, S., Conter, M., Ianieri, A. (2007): Survey on Animal Welfare and Protection during Transport in Northern Italy. Ann. Fac. Medic. Vet. di Parma., 27, 33-42. 